\title{
HMPA-free generation of trialkylsilyl lithium reagents and its application to synthesis of silylboronic esters
}

Received 00th January 20xx, Accepted 00th January 20xx

DOI: $10.1039 / x 0 x \times 00000 x$

\author{
Shintaro Kamio, ${ }^{\mathrm{a}, \mathrm{b}}$ Taiki Imagawa, ${ }^{\mathrm{a}}$ Masaaki Nakamoto, ${ }^{\mathrm{a}}$ Martin Oestreich ${ }^{\mathrm{b}}$ and Hiroto Yoshida*a
}

Trialkylsilyl lithium species have turned out to be facilely generated by treating hexaalkyl disilanes with methyl lithium in the presence of tris( $\mathrm{N}, \mathrm{N}$-tetramethylene)phosphoric triamide (TPPA) as an activator, which can be trapped by boron electrophiles to afford silylboronic esters including long-awaited $\mathrm{Me}_{3} \mathrm{Si}-\mathrm{B}($ pin).

Silylboranes are versatile dimetal reagents for silicon- and boron-installing reactions to provide a variety of organosilicon/boron compounds, which play a pivotal role in modern synthetic organic chemistry. ${ }^{1}$ Silylboranes are generally synthesized by trapping of silyl lithium reagents by boron electrophiles; ${ }^{2}$ the corresponding silyl chlorides are smoothly reduced by lithium metal to afford them, however at least one aryl substituent on the silicon center is necessary for the successful lithiation, ${ }^{3}$ which considerably limits structural diversity of silylboranes to be synthesized (Scheme 1, a). To address this issue, Hartwig developed iridium-catalyzed $\mathrm{Si}-\mathrm{H}$ borylation of silanes that provides convenient and efficient access to trialkyl silylboronic esters, and a similar borylation under rhodium or platinum catalysis was recently reported by Ito (Scheme $1, b) .{ }^{4}$ Although the above catalytic transformations enable differently substituted trialkyl silylboronic esters to be straightforwardly accessed with high efficiency, the application to synthesizing $\mathrm{Me}_{3} \mathrm{Si}-\mathrm{B}$ (pin) meets with difficulties, since low boiling point $\left(6.7{ }^{\circ} \mathrm{C}\right)$ of the parent silane $\left(\mathrm{Me}_{3} \mathrm{Si}-\mathrm{H}\right)$ is incompatible with the heating conditions. In this context, our attention has been directed to new synthetic routes to trialkyl silylboronic esters, especially by employing trialkylsilyl lithium reagents, which are reported to be available via Si-Si bond cleavage of hexaalkyldisilanes with alkyllithium reagents. ${ }^{5} \mathrm{~A}$

\footnotetext{
a. Graduate School of Advanced Science and Engineering, Hiroshima University, Higashi-Hiroshima 739-8526, Japan. E-mail: yhiroto@ hiroshima-u.ac.jp b. Institut für Chemie, Technische Universität Berlin, Strasse des 17. Juni 115, 10623 Berlin, Germany. E-mail: martin.oestreich@tu-berlin.de

† Electronic Supplementary Information (ESI) available: CCDC 2086528. For ESI and crystallographic data in $\mathrm{CIF}$ or other electronic format. See DOI: $10.1039 / \mathrm{x} 0 \times x \times 0000 \mathrm{x}$
}

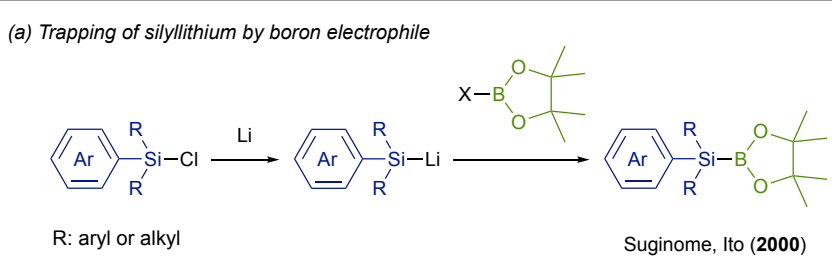
Suginome, Ito $(2000)$

(b) Transition metal-catalyzed Si-H borylation

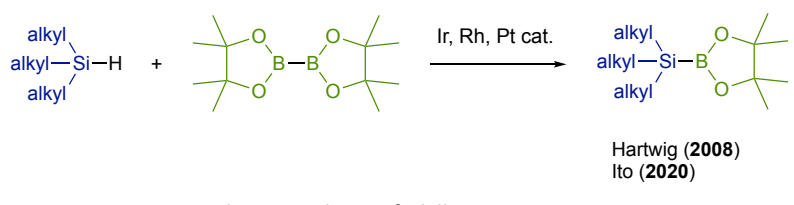

Scheme 1 Previous works on synthesis of silylboronic esters.

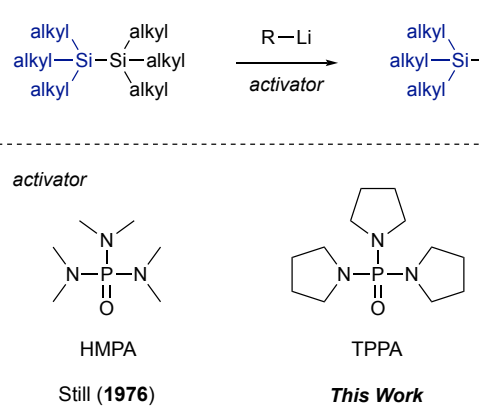

Scheme 2 Formation of trialkylsilyl lithium reagents from disilanes using phosphoric triamides as an activator.

major drawback of this method is that the use of carcinogenic hexamethylphosphoric triamide (HMPA) ${ }^{6}$ as an activator is indispensable, and hence exploration of uncontroversial alternatives is of urgent importance in boron/silicon-based organic synthesis. We present herein that less toxic ${ }^{7} \operatorname{tris}(N, N-$ tetramethylene)phosphoric triamide (TPPA) can serve as a promising substitute for HMPA (Scheme 2 ), ${ }^{8}$ and that trialkylsilyl lithiums thus generated are efficiently convertible into trialkyl silylboronic esters. Furthermore, this study achieved for the first 
Table 1 Optimization of reaction conditions ${ }^{a}$

\begin{tabular}{|c|c|c|c|}
\hline \multirow{2}{*}{$\mathrm{Me}_{3} \mathrm{Si}-\mathrm{SiMe}_{3}$} & \multirow{2}{*}{$\underset{\begin{array}{l}\text { TPPA, Co-solvent } \\
5 \text { min }\end{array}}{\stackrel{\text { MeLi. LiBr }(1 \text { eq })}{\longrightarrow}}$} & \multicolumn{2}{|l|}{$\mathrm{Cl}-\mathrm{Si}^{i} \mathrm{Pr}_{3}(1 \mathrm{eq})$} \\
\hline & & $5 \mathrm{~min}$ & 1 \\
\hline Entry & Co-solvent & Temp $\left({ }^{\circ} \mathrm{C}\right)$ & Yield $(\%)^{b}$ \\
\hline 1 & none & 0 & 12 \\
\hline 2 & THF & -40 & 35 \\
\hline 3 & 2-MeTHF & -40 & 35 \\
\hline 4 & $n$-hexane & -10 & 20 \\
\hline 5 & TMEDA & -40 & 44 \\
\hline $6^{c}$ & TMEDA & -40 & 22 \\
\hline 7 & TMEDA & $-60 \rightarrow 20$ & 73 \\
\hline
\end{tabular}

${ }^{a}$ Conditions: $\mathrm{Me}_{3} \mathrm{Si}-\mathrm{SiMe}_{3}(1.25 \mathrm{mmol}), \mathrm{MeLi} \cdot \mathrm{LiBr}$ in diethyl ether $(1.25 \mathrm{mmol})$, TPPA (1 mL), co-solvent ( $1 \mathrm{~mL}), 5 \mathrm{~min} .{ }^{b} \mathrm{GC}$ yield. ${ }^{c} \mathrm{LiBr}$-free MeLi was used.

time practical, gram-scale synthesis of $\mathrm{Me}_{3} \mathrm{Si}-\mathrm{B}$ (pin), whose reactivity and stability remained to be fully elucidated.

Our studies commenced with the reaction of hexamethyldisilane $\left(\mathrm{Me}_{3} \mathrm{Si}-\mathrm{SiMe}_{3}\right.$ ) and methyllithium lithium bromide complex (MeLi-LiBr) in TPPA as a solvent/activator. The efficiency of $\mathrm{Me}_{3} \mathrm{Si}-\mathrm{Li}$ generation was evaluated by trapping with triisopropylsilyl chloride to observe the formation of $\mathrm{Me}_{3} \mathrm{Si}_{-} \mathrm{Si}^{2} \mathrm{Pr}_{3}$ (1) in $12 \%$ yield (Entry 1, Table 1). Because MeLi-LiBr was found to be poorly soluble in TPPA, we examined the reaction using THF as a co-solvent to observe significant increase in the product yield, wherein the lowering the temperature is necessary to avoid the decomposition of $\mathrm{Me}_{3} \mathrm{Si}-$ Li (Entry 2). The reaction conducted in 2-MeTHF also gave comparable yield of $\mathbf{1}$ (Entry 3 ), and the use of $n$-hexane, whose inert property toward organolithium reagents is utilized for their storing, was unsuccessful (Entry 4). On the other hand, the reaction conducted in $N, N, N^{\prime}, N^{\prime}$-tetramethylethylenediamine (TMEDA) improved the efficiency (Entry 5), whereas the yield became lower by employing LiBr-free MeLi (Entry 6). Finally, the reaction turned out to proceed best in TMEDA at $20^{\circ} \mathrm{C}$ after the addition of $\mathrm{MeLi} \cdot \mathrm{LiBr}$ at $-60{ }^{\circ} \mathrm{C}$ to afford 1 in $73 \%$ yield without any formation of $\mathrm{Me}^{-} \mathrm{Si}^{i} \mathrm{Pr}_{3}$, indicating the complete conversion of MeLi-LiBr (Entry 7).

The generation of $\mathrm{Me}_{3} \mathrm{Si}-\mathrm{Li}$ was further confirmed by transmetalation to $\mathrm{Me}_{3} \mathrm{Si}-\mathrm{Cu}$ with copper(I) iodide in dimethyl sulfide, and their regioselectivities in silylation of allylic phosphates; treatment of diethyl geranyl phosphate (2) with $\mathrm{Me}_{3} \mathrm{Si}-\mathrm{Cu}$ afforded allylsilane 3 in $68 \%$ yield with $\gamma$-selectivity, while $\alpha$-selective silylation took place with

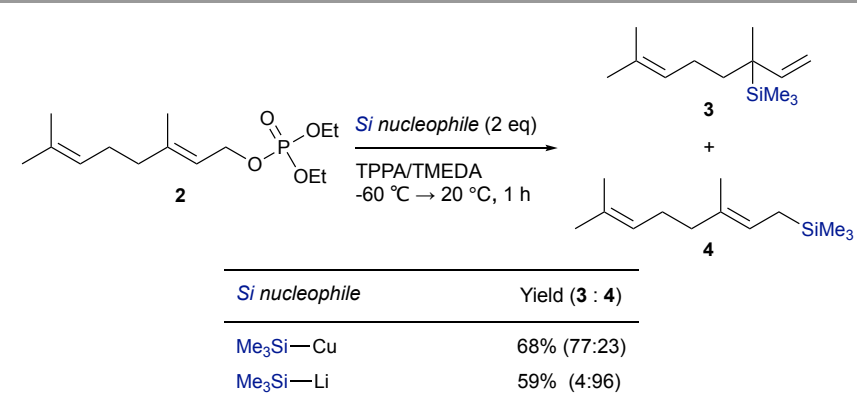

Scheme 3 Regioselective silylation of an allylic phosphate with $\mathrm{Me}_{3} \mathrm{Si}-\mathrm{Cu} / \mathrm{Li}$.

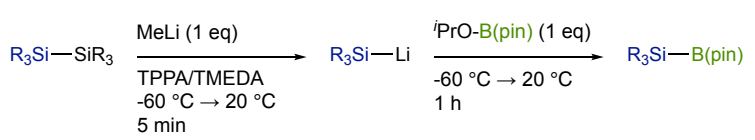

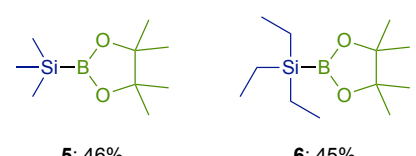

Scheme 4 Synthesis of silylboronic esters via generation of trialkylsilyl lithium reagents.

$\mathrm{Me}_{3} \mathrm{Si}-\mathrm{Li}$ to provide 4, being consistent with an earlier study adopting HMPA system (Scheme 3 ). ${ }^{9}$

With the optimum conditions for generating $\mathrm{Me}_{3} \mathrm{Si}-\mathrm{Li}$ in hand, we next carried out the synthesis of trialkyl silylboronic esters using ${ }^{i} \mathrm{PrO}-\mathrm{B}$ (pin) as a boron electrophile, and found that borylation took place facilely to furnish $\mathrm{Me}_{3} \mathrm{Si}-\mathrm{B}$ (pin) (5) in $46 \%$ yield, being hard to be synthesized by the above catalytic borylation of silanes (Scheme 1, b), which demonstrates the synthetic potential of the present method (Scheme 4). HMPAfree lithiation could also be applied to $\mathrm{Et}_{3} \mathrm{Si}_{-} \mathrm{SiEt}_{3}$ to give $\mathrm{Et}_{3} \mathrm{Si}-$ $\mathrm{Li}$, leading to the smooth formation of commonly used $\mathrm{Et}_{3} \mathrm{Si}-$ $B$ (pin) (6) in $45 \%$ yield. ${ }^{10}$

Furthermore, large scale synthesis of $\mathrm{Me}_{3} \mathrm{Si}-\mathrm{B}(\mathrm{pin})$ became feasible by the present method (Scheme 5 ): the reaction by use of $\mathrm{Me}_{3} \mathrm{Si}-\mathrm{SiMe}_{3}(12.5 \mathrm{mmol})$ afforded $0.97 \mathrm{~g}$ of 5 without significant drop in the yield, showing the synthetic practicality (Scheme 5). It should be noted that $\mathrm{Me}_{3} \mathrm{Si}-\mathrm{B}(\mathrm{pin})$ (5) thus formed can be isolated by silica-gel column chromatography open to atmosphere, and its molecular structure was also determined by X-ray diffraction (Fig. 1). ${ }^{11}$

In conclusion, we have disclosed that commercially available, less toxic TPPA acts as a promising surrogate for HMPA to generate trialkylsilyl lithium reagents that can be utilized for facile synthesis of trialkyl silylboronic esters including $\mathrm{Me}_{3} \mathrm{Si}-$ $B$ (pin). The present method enabled hitherto underexplored $\mathrm{Me}_{3} \mathrm{Si}-\mathrm{B}$ (pin) to be accessed in a gram scale, and would provide a potent solution for gaseous silane problem in the transition metal-catalyzed synthesis of silylbonic esters. Further studies

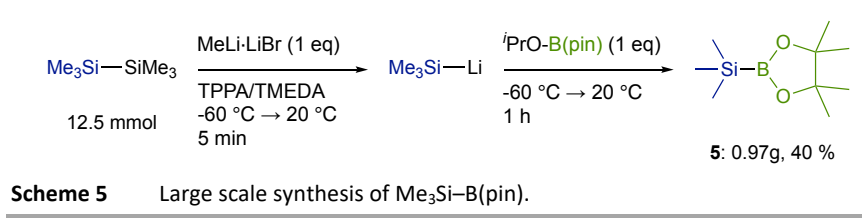

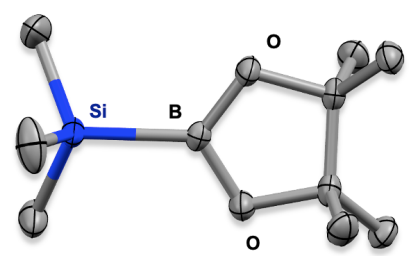

Fig. 1 Solid-state structure of $\mathrm{Me}_{3} \mathrm{Si}-\mathrm{B}(\mathrm{pin})$ with $50 \%$ probability ellipsoids. All of the hydrogen atoms are omitted for clarity. 
on synthesis of new silylboranes as well as their utilization for catalytic silylation/borylation reactions are in progress.

S. Kamio acknowledges JSPS fellowship for young scientists, JSPS KAKENHI Grant Number JP20J14589, and supervision of Prof. Dr. Martin Oestreich in the research stay at Technische Universität Berlin, Germany, supported by JSPS Overseas Challenge Program for Young Researchers.

\section{Conflicts of interest}

There are no conflicts to declare.

\section{Notes and references}

1 For reviews on the chemistry of silylboranes, see: $(a) \mathrm{T}$. Ohmura and M. Suginome, Bull. Chem. Soc. Jpn., 2009, 82, 29; (b) M. Oestreich, E. Hartmann and M. Mewald, Chem. Rev., 2013, 113, 402; (c) J. Feng, W. Mao. L. Zhang and M. Oestreich. Chem. Soc. Rev., 2021, 50, 2010.

2 (a) M. Suginome, T. Matsuda and Y. Ito, Organometallics, 2000, 19, 4647; (b) T. Ohmura, K. Masuda, H. Furukawa and M. Suginome, Organometallics, 2007, 26, 1291.

3 K. Tamao and A. Kawachi, Adv. Organomet. Chem., 1995, 38, 1.

4 For transition metal-catalyzed $\mathrm{Si}-\mathrm{H}$ borylation of silanes, see: (a) T. A. Boebel and J. F. Hartwig, Organometallics, 2008, 27 6013; (b) R. Shishido, M. Uesugi, R. Takahashi, T. Mita, T. Ishiyama, K. Kubota and H. Ito, J. Am. Chem. Soc., 2020, 142, 14125.

5 For $\mathrm{Me}_{3} \mathrm{Si}-\mathrm{SiMe}_{3}$, see: (a) W. C. Still, J. Org. Chem., 1976, 41 3063; (b) P. F. Hudrlik, A. M. Hudrlik, T. Yimenu, M. A. Waugh and G. Nagendrappa, Tetrahedron, 1988, 44, 3791; For other Si-Si bond cleavage reactions, see: $(c) \mathrm{H}$. Gilman, J. M. Holmes and C. L. Smith, Chem. Ind., 1965, 848; (d) B. K. Nicholson and J. Simpson, J. Organomet. Chem., 1974, 72, 211; (e) H. Gilman and C. L. Smith, J. Organomet. Chem., 1968, 14, 91; $(f)$ G. Gutekunst and A. G. Brook, J. Organomet. Chem., 1982, 225, 1.

6 For Biological effects of HMPA, see: $(a) \mathrm{H}$. Jackson, A. Jones and E. Cooper, J. Reprod. Fert., 1969, 20, 263; (b) A. Jones and H. Jackson, Biochem. Pharmacol., 1970, 19, 603; (c) R. Kimbrough and T. Gaines, Bull. EnViron. Contam. Toxicol., 1973, 10, 225; (d) J. A. Zapp Jr., Am. Ind. Hyg. Assoc. J., 1975, 36, 916; (e) K. P. Lee and H. J. Trochimowicz, J. Natl. Cancer Inst., 1982, 68, 157; (f) C. P. Mihal Jr., Am. Ind. Hyg. Assoc. J., 1987, 48, 997; $(g)$ I. Aguirrezabalaga, M. Nivard, M. Comendador and E. Vogel, Genetics, 1995, 139, 649.

7 Carcinogenicity of HMPA is due to hydroxylation at $N$-methyl groups by cytochrome P450 enzymes with concomitant release of formaldehyde within the nasopharyngeal cells, see ref $5 b$. Besides, hexaethyl phosphoric acid triamide (HEPA) is reported to be non-carcinogenic. See ref $7 c$, and J. A. Zilstra, Proefschrift, Rijks-Universiteit Leiden, 1987 and references cited therein. Moreover, higher boiling point of TPPA could also contribute to the less toxicity, as is the case with diHMPA, see ref $7 a$.

8 A small number of reactions employing HMPA surrogates have been reported, see: (a) C. E. McDonald, J. D. Ramsey, J. A. Grant and K. A. Howerter, Tetrahedron Letters, 2009, 50, 5308; (b) C. E. McDonald, J. D. Ramsey, D. G. Sampsell, J. A Butler and M. R. Cecchini, Org. Lett., 2010, 12, 5178; (c) M. Berndt, A. Hölemann, A. Niermann, C. Bentz, R. Zimmer and H.-U. Reissig, Eur. J. Org. Chem., 2012, 1299.
9 J. G. Smith, S. L. Henke, E. M. Mohler, L. Morgan and N. I. Rajan, Synth. Commun., 1991, 21, 1999.

10 Use of $\mathrm{LiBr}$-free MeLi was effective for the lithiation of $\mathrm{Et}_{3} \mathrm{Si}-$ $\mathrm{SiEt}_{3}$, see ESIt for details.

11 CCDC 2086528 contains the supplementary crystallographic data for this papert. 